\title{
International entrepreneurship of universities: Process-oriented and capabilities perspectives
}

\author{
Łukasz Sułkowski, Zofia Patora-Wysocka
}

\begin{abstract}
A B S T R A C T
Objective: The objective of the article is to propose a model of process-oriented dimension and capabilities perspective on the basis of existing literature and the concept of university-based international entrepreneurship.

Research Design \& Methods: The article is conceptual and based on scientific literature from online databases. The method used in the research was the critical and reflective analysis of published research results in the area of process-oriented dimension and capabilities perspective for the international entrepreneurship of universities.
\end{abstract}

Findings: An entrepreneurial university is mainly supported by incremental changes flowing from organisational identity and culture. Leadership is strongly concentrated on sense-making. The creative processes in HEI's are of entrepreneurial and social nature. Process-oriented and capabilities perspectives consist of a useful cognitive base for explaining entrepreneurial activities of universities.

Implications \& Recommendations: Dominant functionalistic approach to the entrepreneurship of universities does not fully explain the social nature of activities of HEl's. To develop entrepreneurial orientation in $\mathrm{HEI}$, leaders should concentrate on sense-making and sense-giving.

Contribution \& Value Added: Process-oriented dimension and capabilities perspective for the international entrepreneurship of universities is a new approach in management theory. Cognitive value lies in the novel approach to entrepreneurial universities as benefiting from the interpretative paradigm and incrementalism.
Article type: conceptual article
Keywords:
international entrepreneurship; higher education; entrepreneurial university; entrepreneurship in higher education

JEL codes:

Received: 27 March 2020 Revised: 16 July 2020 Accepted: 16 July 2020

\section{Suggested citation:}

Sułkowski, Ł., \& Patora-Wysocka, Z. (2020). International entrepreneurship of universities: Processoriented and capabilities perspectives. Entrepreneurial Business and Economics Review, 8(3), 175188. https://doi.org/10.15678/EBER.2020.080310 


\section{INTRODUCTION}

Over the last years, academic entrepreneurship drew considerable attention in the literature (Wright, Lockett, Clarysse, \& Binks, 2006; Evers, Cunningham, \& Hoholm, 2016). Entrepreneurial performance of a university was explored mainly through the lens of knowledge creation, i.e. spin-off enterprises, incubator firms and networks, the commercialisation of intellectual property, technology transfer, but also commercial teaching practice or non-state research grants (Etemad, 2016). That kind of research orientation is partly a consequence of social identity of universities, based upon achieving research excellence. However, in practice, it may collide with the traditional ethos of an academic institution manifested in scientific autonomy and resistance to managerial expertise (Jarzabkowski, 2005). On top of the above, there is the issue of global disruptive developments, i.e. rapid economic growth, value creation, technology and knowledge development, and internationalisation (Etemad, 2016). As a result, the commercial activity of universities has recently received relatively strong attention as part of efforts to contribute to the growing body of research on international entrepreneurship. Therefore, an academic spin-off, as "a new firm created to exploit commercially some knowledge, technology, or research results developed within a university" (Evers et al., 2016, p. 287) coincides with a plethora of theoretical approaches in international entrepreneurship agenda.

The objective of the article is to propose the concept of process-oriented dimension and capabilities perspective for international entrepreneurship of universities on the basis of existing literature. The topic is important because the vast majority of literature about entrepreneurial university utilises functional paradigm, and there is a theoretical and methodological gap in the interpretative understanding of the entrepreneurship of higher education institution (HEl; Dzimińska et al., 2020). Process-oriented and capabilities approach represents a new and fruitful theoretical and methodological ground for the research of post-Humboldtian university (Sułkowski, 2016a).

Hence, the research question of the article is: how to describe entrepreneurial university using process-oriented dimension and capabilities perspective?

The article starts with the description of the method selected to perform the study, followed by the presentation of literature review results, including the study of such concepts as entrepreneurial university and international entrepreneurship. The main part of the article is the outline of the proposed model: developing a process-oriented and capabilities perspective of university-based international entrepreneurship framework. The article closes with conclusions and recommendations for further research.

\section{MATERIAL AND METHODS}

The article is based on scientific literature taken out from online databases. It is a theory development article, which relies on the literature review and desk research. The method used in the research was a critical and reflective analysis of the published research results in the area of process-oriented dimension and capabilities perspective in the international entrepreneurship of universities. The selection of articles included in the analysis was a two-stage process. The critical and reflective screening of the phrases "entrepreneurial university," "process-oriented dimension and capabilities perspective," and "international 
entrepreneurship of universities" was performed in the Scopus and Google Scholar databases. The widest screening led to more than 27900 articles. By limiting the search by joining the search phrases "entrepreneurial university" and "international entrepreneurship of universities" we narrowed it down to 1604 articles. The choice of cited articles from this pool formed the main body of analysis based on 51 texts. A joint query for "process-oriented" or "capabilities perspective" with "entrepreneurial university" and "international entrepreneurship of universities" gives no results. The lack or very limited number of articles on this subject suggest that there may be a research gap.

Our article is a conceptual text based on building a new approach to entrepreneurship of HEl's. Literature review and desk research offer a new perspective that should be developed in further qualitative and quantitative research programs. Scientific approach applied in this article is qualitative and includes the following methods: secondary qualitative data analysis, predictive synthesis, induction, and description.

\section{LITERATURE REVIEW AND THEORY DEVELOPMENT}

\section{Entrepreneurial University}

Numerous researchers indicate the diverse directions of contemporary universities development. There prevails a view on the transformation of universities into business market organisations that will pursue concepts of new public management (de Boer, Enders, \& Schimank 2007; Hood 1995). Higher education institutions become the "producers" of educational services available at the competitive market, which simultaneously constitutes the implementation of economic and commercial approaches. This equally concerns teaching students and research conducted by employed teachers. The final shape of the new model has not been determined yet but, according to Ronald Barnett (2000), it will allow for resurrecting the organisation referred to as the university.

Sporn (2006) indicates three general approaches to the management of higher education institutions, i.e. new public management, entrepreneurialism, and academic capitalism. According to Sporn (2006), as far as higher education institutions in the EU are concerned, new public management has focused on establishing and reinforcing educational quality management systems based on Total Quality Management (TQM). This is the example of both the United Kingdom and Scandinavian countries. Other methods of management used in higher education institutions and motivated by new public management include project management, contract management, assessment, audit and accreditation, institutional autonomy, and accounting.

Entrepreneurial university is a concept developed and popularised by Clark (1998). After a study of five universities and their ability to react to challenges posed by the environment, he distinguishes five variables. The entrepreneurial university is characterised by Clark (1998) as having:

- a strong managerial and leadership core,

- an integrated entrepreneurial culture,

- a diverse origin of higher education institution funds,

- developing and expansive peripheral areas,

- a stimulating heart of academic activities. 
The strong managerial and leadership core means a high level of organisational autonomy accompanied by differentiation between professional managers/administrators and the academic structure. Entrepreneurial culture is the source of identification for university employees which combines individual and institutional autonomy. Diverse higher education institution financing leads to the reinforcement of autonomy, independence, and economic security. Entrepreneurial universities are increasingly investing in new technologies, startups, and spin-offs. All of these aspects of the entrepreneurial university develop on a highquality basis in the form of educational and research activities (Sporn, 2006).

Higher education is increasingly becoming a business activity, in which competitiveness plays the key role. These changes reinforce actions taken by the executive committee composed of leaders of respective units. There also emerges a group of professional managers and administrators in educational activities (Sporn, 2006).

Moreover, there is a significant connection between higher education and entrepreneurship. The Total Entrepreneurship Activity index measures the correlation between starting a business activity and the level of education. The level of entrepreneurship measured with the help of this index significantly correlates with education (Bloom, Hartley, \& Rosovsky, 2007). The results of the study conducted in 17 countries confirm this relation.

Progressive changes in the contemporary management of higher education institutions may be described with the help of three tendencies: shared management; corporate and entrepreneurial approach; flexible and learning architecture (Sporn, 2006).

There also appear distinctive features of entrepreneurial university include strategy, structure, and system entrepreneurial culture, which constitutes a radical change of academic culture. Shattock defines academic entrepreneurship as the "aspiration for the identification and maintenance of the clear institutional agenda determined by the very institution but not constituting the product of the state financing formula" (Shattock \& Temple, 2006, pp. 1-2). Entrepreneurial universities are described on the basis of such concepts as entrepreneurship, proactivity, adaptability, and learning organisation (Sporn, 1999a; Sporn, 1999b; Sporn, 2001).

In the literature, there appears a list of features of the liberal (traditional, Humboldtian) and entrepreneurial university - based on Clark's concept - which includes six criteria: the role of the controlling centre, the higher education institution's organisational structure, relationship of the higher education institution with the environment, financing operations, a stimulating academic centre, entrepreneurial culture and academic values. It seems that these six criteria can be complemented with additional four, namely university mission, an approach to organisational changes, higher education institution bureaucratisation, and management model (Sułkowski, 2016b).

\section{International Entrepreneurship}

Recent efforts to disentangle the increasingly complex conceptual approach to international entrepreneurship (IE) have focused on finding common intersections of research areas, namely entrepreneurship, international business, strategy, operations management, and networks (Etemad, 2017). The very basic demarcation line between international business and entrepreneurship became hardly recognisable since internationalisation is no more a privilege of multinational corporations (MNCs). Instead, it is the domain of small and medium-sized businesses and new venture creations, as one of key business activities in contemporary world (McDougall \& Oviatt, 2000). Therefore, there is the need 
to understand IE as a fusion of theoretical categories from various fields of study as long as entrepreneurship is a generic phenomenon for entrepreneurial actions and agency (Eckhardt \& Shane, 2003; Jones \& Coviello, 2005), innovation, serendipity, and individual opportunism issues (Schumpeter, 1934; Kirzner, 1997; Shane \& Venkataraman, 2000), creativity (Autio, 2005), organisational change and strategic management (Shane, 2003). Due to the abundant literature and research issues, there lingers the lack of unified theoretical and methodological lens. Moreover, there is a fundamental discourse on whether IE is a field of research at all (Servantie, Matthieu, Gilles, \& Boissin, 2016). Given the above, the challenge is to differentiate between analytically diverse aspects of observing IE phenomena. The dualistic thinking of process-oriented versus capabilities perspective aspects of IE may contribute to this debate. The process-oriented perspective tackles the issue of entrepreneurial actions in terms of their inner dynamics. It is of twofold character: recursive and simultaneously mutable. Then, capabilities orientation traces back to the work of Nelson and Winter (1982). The analysis shows that there appear routines (not their inner structure) that are perceived as basic units of analysis (Tsoukas, 2017). These theoretical lens may provide a conceptual foundation for developing a comprehensive framework for a university-based IE perspective.

IE has been a vivid research subject from the late 1980s (McDougall, 1989; Oviatt \& McDougall, 1994). The very first definitions put emphasis on the incremental path of internationalisation. Since the IE was described as: the development of international new venture or start-ups that - from their inception - engage in international business, thus viewing their operating domain as international from the initial stages (McDougall, 1989, p. 387) appears as the 'trace' of evolutionary logic in the model by Johanson and Vahlne (1977). Simultaneously, emphasis is also put on entrepreneurial activities such as venturing, engaging, and operating, which a clearly turns towards issues of entrepreneurial agency. Further elaboration of IE happened in the 1990s and 2000s, by exploring resourcebased and network orientations (Young, Dimitratos, \& Dana, 2003), along with performative aspects of human activity (Styles \& Seymour, 2006). However, in the area of entrepreneurial actions, there seems to remain a cognitive gap in the realm of adopting the activitybased view of strategy as practice in IE issues (Jarzabkowski, 2005; Johnson, Langley, Melin, \& Whittington, 2007; Becker, 2010; Hernes, 2014). Thus, introducing process-oriented and capabilities perspectives into the context of IE should allow us to observe entrepreneurial activity from two complementary viewpoints.

\section{International Entrepreneurship: Process-Oriented Dimension}

The notion of a process in the very basic understanding of the term means the continuous making and moving of forms (Cooper, 2015, p. 585). Process may be seen as actions, events, and physical and mental acts of doing something that is located in time and space. In entrepreneurial reality, a process refers to the plan, performance, and realisation of intentions and opportunities. A human agent is the key factor of constituting reality, however, there is a plethora of interactions among humans, artefacts, technology and the natural, and the social world. Since the business and entrepreneurial reality is 'on the constant move,' we can infer that the process is the continuous coming-to-presence of the forms and objects of everyday life rather than their taken-for-granted, ready-made presences (Cooper, 2015, p. 585). The very premises of process thinking may appear as a starting point of defining the process orientation in IE's field. 
Tracing back the process-oriented concept of IE, we may begin with the definition by McDougall (1989, p. 293), who recognises IE as new and innovative activities that have the goal of value creation and growth in business organisations across national borders. The definition is dominated by performative phrases such as "innovative activities" and "value creation." There is a clear departure from age or size issues that initially limited the observation of internationalisation to MNEs. Later, McDougall and Oviatt revisited old definitions to emphasise such categories as proactive and risk-seeking behaviour (2000, p. 903) or the discovery, enactment, evaluation, and exploitation of opportunities (Oviatt \& McDougall, 2005; Keupp \& Gassmann, 2009), while others foregrounded learning advantages of newness (Zahra, Zheng, \& Yu, 2018). Therefore, the entrepreneurship process is a never-completed act of creating and redefining activity and gaining practical knowledge on a daily basis. At the same time, the entrepreneurship process is of purposive, projective, and reflexive character, aimed at growing and opportunity-seeking. Practical and evaluative aspects of problem solving are context-dependent, and they form participatory acts under construction (Cooper, 2015). Thus, in the IE literature, there is a plethora of works exploring the problem of uncertainty and risk (Liesch, Welch, \& Buckley, 2011). However, when evaluating the situation-specific issue of uncertainty and risk, individual perception may differ from other organisational members' interpretation. The processual generic problem of interlinked activities is the potential source of ideas for exploring that issue (Simpson \& Lorino, 2016). Another key aspect of process orientation in IE is the problem of timing. Referring to the very first characteristics of INVs (Oviatt \& McDougall, 1994; Knight \& Cavusgil, 1996), one may infer a strong link between temporality, entrepreneurial activities, and opportunism. Patterns of internationalisation in entrepreneurial organisations may be fundamentally different from the model of strategically planned stages. The timing dimension refers to activities to be internationalised from their inception, as a result of seeking to derive much of revenues from sales abroad (Aspelund \& Moen, 2005) or establishing a startup operating abroad (Knight \& Cavusgil, 2004). Another timing issue seems to highlight fragmented characteristics of internationalisation processes and the possibility of withdrawal or disappearance of an internationalisation practice (Welsh \& Loustarinen, 1993). Thus, internationalisation activity is only a generative mechanism that - under context-specific circumstances - can result in a tendency to reproduce given activity patterns or a decision to cease them completely. In this light, time is a resource used by entrepreneurs to create temporal advantages (Hernes, 2014). As Cooper (2015) indicates, the notion of process etymologically bears the meaning of the production and disappearance of forms. Therefore, process means approach and withdrawal (2014, p. 585). Thus, IE can be placed under the premises of processual practice theories that analyse the linkage between activities, agency, and structure (Golsorkhi, Rouleau, Seidl, \& Vaara, 2010).

Styles and Seymour (2006) establish an analytical framework of emerging fields of interest in IE. In fact, there are several gaps in the literature that could be categorised as follows: opportunity, human action and behaviour, learning, creativity and innovation, exchange aspects of internationalisation, performance (Styles and Seymour, 2006, pp. 137139). Summing up, at the core of the process-oriented dimension there are such constitutive categories as entrepreneurial activities, processual emergence, interactions, and opportunism, along with context-related issues like uncertainty, risk, and temporality. Process thinking in IE seeks activity flow, internationalisation patterns formation, movement 
in networks, interactions, and time-oriented issues. It may contribute to our understanding of internationalisation processes by clarifying mechanisms of their constant change.

\section{International Entrepreneurship: Dynamic Capabilities}

A capabilities perspective in IE emerged in order to find explanatory factors that not only facilitate internationalisation activities but also sustain their long-term competitive advantages. At first sight, the capabilities perspective may seem to stand in a complete opposition to a process-based orientation in IE in as far as the latter is aiming at exploring performative nature of IE. However, to paraphrase Hernes (2014), a world on the move invites dispositions for organisations that - in order to keep performance indicators high - need to respond to the continuous flow of challenges, opportunities, people, goods, technology, and time. Teece (2009) identifies a dynamic capabilities conception that overlaps the resource-based theory of the firm and the evolutionary economics perspective by Nelson and Winter (1982). According to Al-Ali and Teece (2014, p. 105), entrepreneurship is one of the constitutive aspects of dynamic capabilities that stand as "higher-order capabilities in the sense that they govern how the organisation's ordinary capabilities are developed, augmented, winnowed, and combined." These are the key categories that unfold processes possibly impeded by the inertial use of ordinary resources. These categories are the linkage between organisational tendency to maintain daily routines, learn in practice, and adapt to changes. The concept of dynamic capabilities provides a promising approach to IE. Since entrepreneurial activities may introduce a new activity scheme abroad, there are efforts to successfully accomplish these activities on a daily basis. The process of activity patterns replication begins. Teece (1976) assumes that this kind of reproducing activities is very often costly in markets abroad. The learning processes are crucial as far as different spatial and situational contexts are concerned. Thus, strong dynamic capabilities are needed (Al-Aali \& Teece, 2014, p. 109). The timing problem arises when opportunities of market mode entry collide with the need to transfer capabilities from a domestic market. Moreover, even if organisational resources are unique, it is not unreasonable to search for new capabilities or try to renew the old ones. In a competitive environment, the competitive advantage is not a long-lived category. There are adaptations needed along with the capability to redeploy crucial management skills, routines, and values (Teece, 2007). Pentland et al. (2012) put that kind of challenging processes in "sociomaterial" brackets of information and communication technology. The application of trackable routines proves to work under ICT modular services that allow replication on the one hand, and flexible reconfiguration on the other hand (2012). In the context of international entrepreneurship, the flexibility aspect of interactions between entrepreneurs and technology is of great importance. Zahra et al. (2018) show that learning is not an imperative. Instead, the point is to learn how to learn $(2018$, p. 31). IE implies a dedication to observing, expressing, catching, and assimilating what is worth learning.

\section{The Proposed Model: Developing a Process-Oriented and Capabilities Perspective of University-Based International Entrepreneurship Framework}

Process-oriented and capabilities perspectives introduce a complementary view of IE. While the premises of process thinking conceptualise the entrepreneurship issues in the realms of activity-based domain, the capabilities view contributes to explaining these performative as- 
pects of activities originating from capabilities of individuals and collectives. Our article harnesses the process and capabilities agenda to fill the gap in university-based IE.

The aim of this part of the article is to build aspects of process- and capabilities-orientation into the university IE framework.

The first and foremost mission of the university is developing and communicating the state of knowledge. Thus, university-based R\&D generate much of intellectual good and property. Commercialisation is a different and absorbing area of activity. Etemad (2016) pinpoints that besides the small number of scientists-turned-entrepreneurs who can pursue business activities, scientific and managerial lives stand in clear opposition (2016, p. 279). As Slaughter and Leslie (1999) show, many academics perceive teaching and incomegenerating activities - and thus research and teaching - as activities of divergent characteristics. Analogically, the same pattern may be present in commercial and research activities: managerial values seem to oppose scientific values. Therefore, if these are the very roots of tension, we may agree that the university is an organisation of fragmented professional workforce and multiple contradictory activities that create tensions between professional and managerial interests (Jarzabkowski, 2005, p. 73).

There are several aspects insufficiently explained in theoretical and empirical terms in process-oriented IE. The everyday practice of creating and commercialisation of knowledge may form a strategic challenge for universities and spin-offs. Summing up, there are several criteria that guide the exploration of university-based IE issues in process-based frames of reference:

1. When pursuing practice as the main object of analysis, it could be possible to observe challenging issues in terms of day-to-day reproduced schemas of action. The university as an organisation of highly autonomous professional workforce is not a place susceptible to top-down management (Jarzabkowski, 2005). If we take into account the premise that activities are situated in the social context (Howard-Grenville, 2005), then understanding the university as having the primacy of external power over the individuals, or the other way round, is a false thesis. Practice 'omits' structures and people as causes of phenomena and, instead, seeks to observe activities.

2. Entrepreneurial processes (activities) may be of emergent, recursive, and temporal character. Performative aspects of daily activities may be transferred onto the issue of (de)internationalisation issues and change management.

3. The traditional view of practice and everyday activities is rooted in pragmatism and the interpretative paradigm (Dewey, 1938; Weick, 1995). In terms of the university context, there remains the importance of interactions between agents: divergent and emerging goals, decision-making process, sense-making, and shared-understanding issues. Evers et al. (2016) pursue the problem of non-academic actors in university- based IE context. We may add that the university deals with the problem of agency because there are not only individuals involved in performance abroad. There are networks, routine schemas, values, technologies, and artefacts that create a complex context.

4. Last but not least, opportunities as the key factor of founding entrepreneurship theory play an important role in university-based IE. Entrepreneurs take advantage of unplanned situations as much as scientists use opportunities to develop scientific ideas. In the entrepreneurship reality, the generated knowledge becomes a product. It opens up a wide lens on the process dimension of university-based IE. 
In a very broad sense, an entrepreneurial university as a capability-oriented category emphasises sustaining competitive advantages. Teece (2009, p. 168) conceptualises dynamic capabilities in MNEs in terms of five crucial categories: 1 ) learning and innovation, 2) competences in 'designing' business, 3) heuristic decision-making on investment allocation, 4) the orchestration of assets with competence in bargaining, 5) efficient governance. These five characteristics provide a valuable context for research into universitybased IE in realms of long-term performance. A university-based venture consists of mixed and - very often - divergent experience of venture capitalists and scientists (Mikhailova \& Olsen, 2016), which may be an obstacle in the very early phase of internationalisation; however, it may also provide the basis for a superior spin-off's performance and development in the long run. According to Mikhailova and Olsen (2016), these are the business and scientific networks that form the background for moving ventures onto next levels. In that sense, Evers et al. (2016) recognise the particular role of learning and resourcing. These aspects are accompanied by the time dimension, the liabilities of newness, foreign entourage, and overarching unpredictability (Evers et al., 2016, p. 290). Putting such capabilities view into a practice-based orientation, we may cover at least three aspects of learning as the processual category of experience and knowledge creation:

1. the concept of 'knowing-in-practice' that is grounded in the practical involvement of actors in operations (Gherardi, 2012),

2. the notion of 'practice-in-use' and 'technology-in-use' (Orlikowski, 1996) that contributes to observing capacities of merging material objects and technology and activities, and

3. reflexivity (Beck, Giddens, \& Scott, 2009) that is the basis of practice-learning and stimulates the ordinary capabilities of their augmentation, development, and improvement.

\section{CONCLUSIONS}

The prevailing trend of contemporary HEl's transformation is the deepening development of 'entrepreneurial university' models, accompanied by the growing wave of criticism and resistance from the academic environment. The development of entrepreneurial tendencies in university culture manifests itself through, e.g.:

- the focus on generating revenues from scientific and educational activities,

- the pursuit of market mission and the establishment of competitive strategies,

- the orientation on creating and implementing innovations coming from scientific activities together with industry,

- the adoption of quasi-business and quasi-corporate organisational solutions within strategic and structural spheres,

- the introduction of accountability methods and governance controlling methods,

- the shift in the process of decision-making from the collegial model oriented on academics towards the managerial model conferring power upon management boards, administrators, and governing bodies.

In conclusion, we may propose characteristics of entrepreneurship of HEl's based on process-oriented and capabilities perspectives. Answering the research question, we could describe an entrepreneurial university as mainly based on incremental changes flowing from organisational identity and culture. Moreover, the type of leadership is strongly concentrated on sense-making and building the consensus around stakeholders' actions. 
Universities are knowledge-creating organisations. The creative process is entrepreneurial and social. Process-oriented and capabilities perspectives constitute a useful cognitive basis for explaining entrepreneurial activities of universities.

The implications of above conclusions for policymakers and leaders of HEl's are important. The dominant functionalistic approach to the entrepreneurship of universities does not explain the social nature of university actions (Sułkowski, 2012). To develop the entrepreneurial orientation in HEI leaders should concentrate on sense-making and sense-giving that promote the value of creative, open, and flexible actions of organisational actors (Sułkowski, 2017).

The limitation of our research is the speculative character of theoretical construction. There is a need to build a research program based on primary data that goes deeper into the process-oriented and capabilities perspectives of HEl's.

The perspective for future research is to use the grounded theory approach to build and test models of process-oriented and capabilities perspectives for entrepreneurship in universities. What could be important is the difference between entrepreneurial actions of different types of HEl's such as public and private universities.

\section{REFERENCES}

Al-Aali, A., \& Teece, D.J. (2014). International Entrepreneurship and the Theory of the (LongLived) International Firm: A Capabilities Perspective. Entrepreneurship Theory and Practice, 38(1), 95-116.

Aspelund, A., \& Moen, $\varnothing$. (2005). Small international firms: Typology, performance and implications. Management International Review, 1(1), 37-57.

Autio, E. (2005). Creative tension: The significance of Ben Oviatt's and Patricia McDougall's article towards a theory of international new ventures. Journal of International Business Studies, 36(1), 9-19.

Barnett, R. (2000). Thinking the University, Again. Educational Philosophy and Theory, 32(3), 319-326.

Beck, U., Giddens, A., \& Scott, L. (2009). Modernizacja refleksyjna: Polityka, tradycja i estetyka w porzqdku społecznym nowoczesności. Warszawa: PWN.

Becker, M. (Ed.). (2010). Handbook of organizational routines. Cheltenham: Edward Elgar Publishing Limited.

Bloom, D.E., Hartley, M., \& Rosovsky, H. (2007). Beyond Private Gain: The Public Benefits of Higher Education. In J.J.F. Forest, \& P.G. Altbach (Eds.), International Handbook of Higher Education. Springer International Handbooks of Education (vol 18). Dordrecht: Springer.

Cooper, R. (2015). Process and Reality. In J. Helin, T. Hernes, D. Hjorth, \& R. Holt (Eds.), Process Philosophy and Organization Studies (pp. 585-605). Oxford: Oxford University Press.

de Boer, H., Enders, J., \& Schimank, U. (2007) On the Way towards New Public Management? The Governance of University Systems in England, the Netherlands, Austria, and Germany. In D. Jansen (Eds.), New Forms of Governance in Research Organizations. Dordrecht: Springer.

Dewey, J. (1938). Experience and Education. New York: Kappa Delta Pi.

Dzimińska, M., Fijałkowska, J., \& Sułkowski, Ł. (2020). A Conceptual Model Proposal: Universities as Culture Change Agents for Sustainable Development. Sustainability, 12(11), 4635.

Eckhardt, J.T., \& Shane, S.A. (2003). Opportunities and entrepreneurship. Journal of Management, 29(3), 333-349. 
Etemad, H. (2016). Special Thematic Issue on: International Interactions and Activities of UniversityBased Technology Entrepreneurship. Journal of International Entrepreneurship, 14, 277-284.

Etemad, H. (2017). The emergence of online global market place and the multilayered view of international entrepreneurship. Journal of International Entrepreneurship, 15, 353-365.

Evers, N., Cunningham, J.A., \& Hoholm, T. ( 2016). International entrepreneurship in universities: Context, emergence and actors. Journal of International Entrepreneurship, 14, 285-295.

Gherardi, S. (2012). How to conduct a practice-based study. Northampton: Edward Elgar.

Golsorkhi, D., Rouleau, L., Seidl, D., \& Vaara, E. (2010). Cambridge Handbook of Strategy as Practice. Cambridge: Cambridge University Press.

Hernes, T. (2014). A Process Theory of Organization. Oxford: Oxford University Press.

Hood, C. (1995). Contemporary public management: A New Global Paradigm?. Public Policy and Administration, 10(2), 98-105.

Howard-Grenville, J., (2005). The Persistence of Flexible Organizational Routines: The Role of Agency and Organizational Context. Organization Science, 16(6), 618-36.

Jarzabkowski, P. (2005). Strategy as practice. An activity based approach. London: Sage Strategy Series, Sage Publications.

Johanson, J., \& Vahlne, J.E. ( 1977). The Internationalization Process of the Firm - A Model of Knowledge Development and Increasing Foreign Market Commitments. Journal of International Business Studies, 8(1), 23-32.

Johnson, G., Langley, A., \& Melin, L., Whittington, R. (2007). Strategy as practice. Research Dimensions and Resources. Cambridge: Cambridge University Press.

Jones, M.V., \& Coviello, N.E. (2005). Internationalization: conceptualizing an entrepreneurial process of behavior in time. Journal of International Business Studies, 36(3), 284-303.

Keupp, M.M., \& Gassmann, O. (2009). The Past and the Future of International Entrepreneurship: A Review and Suggestions for Developing the Field. Journal of Management, 35(3), 600-633.

Kirzner, I.M. (1997). Entrepreneurial discovery and the competitive market process: an Austrian approach. Journal of Economic Literature, 35, 60-85.

Knight, G.A., \& Cavusgil, S.T. ( 1996). The born global firm: a challenge to traditional internationalization theory. Advances in International Marketing, 8, 11-26.

Knight, G.A., \& Cavusgil, S.T. ( 2004). Innovation, organizational capabilities and the born-global firm. Journal of International Business Studies, 35(2), 124-141.

Liesch, P.W., Welch, L.S., \& Buckley, P.J. ( 2011). Risk and Uncertainty in Internationalisation and International Entrepreneurship Studies Review and Conceptual Development. Management International Review, 51, 851-873.

McDougall, P.P. (1989). International vs domestic entrepreneurship: a comparison of new venture behavior and industry structure in the computer and communications industries. Journal of Business Venturing, 4, 387-400.

McDougall, P.P., \& Oviatt, B.M. (2000). International entrepreneurship: The intersection of two research paths. Academy of Management Journal, 43, 902-908.

Mikhailova, O., \& Olsen, P.I. (2016). Internationalization of an academic invention through successive science-business networks: The case of TAVI. Journal of International Entrepreneurship, 14(3), 441-471.

Nelson, R., \& Winter, S. (1982). An Evolutionary Theory of Economic Change. Cambridge: Harvard University Press.

Orlikowski, W. (1996). Improvising Organizational Transformation Over Time: A Situated Change 
Perspective. Information Systems Research, 7(1), 63-92.

Oviatt, B.M., \& McDougall, P.P. (1994). Towards a theory of international new ventures. Journal of International Business Studies, 25(1), 45-64.

Oviatt, B.M., \& McDougall, P.P. (2005). The internationalization of entrepreneurship. Journal of International Business Studies, 36(1), 2-8.

Pentland, B.T., Feldman, M.S., Becker, M.C., \& Liu, P. (2012). Dynamics of Organizational Routines: A Generative Model. Journal of Management Studies, 49(8), 1484-1508.

Schumpeter, J.A. (1934). Change and the Entrepreneur. Cambridge, MA: Harvard University Press.

Servantie, V., Matthieu, C., Gilles, G., \& Boissin, J.P. (2016). Is international entrepreneurship a field? A bibliometric analysis of the literature (1989-2015). Journal of International Entrepreneurship, $14,168-212$.

Shane, S., \& Venkataraman, S. (2000). Promise of entrepreneurship as a field of research. Academy of Management Review, 25(1), 217-226.

Shane, S. (2003). A General Theory of Entrepreneurship: The Individual-Opportunity Nexus. Cheltenham: Edward Elgar.

Shattock M., \& Temple P. (2006). Entrepreneurialism and the Knowledge Society: some conclusions from cross national studies (paper presented at the EAIR Forum, Rome).

Simpson, B., \& Lorino, P. ( 2016). Re-Viewing Routines through a Pragmatist Lens. In J. HowardGrenville, C. Rerup, A. Langley, \& H. Tsoukas (Eds.), Organizational Routines: How They are Created, Maintained, and Changed (pp. 47-70). Oxford: Oxford University Press.

Slaughter, S., \& Leslie, L. ( 1999). Academic Capitalism, Politics, Policies, and the Entrepreneurial University. Baltimore, MD: Johns Hopkins University Press.

Sporn, B. (2006). Governance and Administration: Organizational and Structural Trends. In: J.J.F. Forest, Ph.G. Altbach (Eds.), International Handbook of Higher Education. Dordrecht: Springer.

Sporn, B. (1999a). Towards More Adaptive Universities: Trends of Institutional Reform in Europe. Higher Education in Europe, 24(1), 23-33.

Sporn, B. (1999b). Adaptive University Structures. An Analysis of Adaptations to Socioeconomic Environments of US and European Universities. London: Jessica Kingsley.

Sporn, B. (2001). Building Adaptive Universities: Emerging Organisational Forms Based on Experiences of European and US Universities. Tertiary Education and Management, 7, 121-134.

Styles, C., \& Seymour, R. (2006). Opportunities for marketing researchers in international entrepreneurship. International Marketing Review, 23(2), 126-145.

Sułkowski, Ł. (2016a). Accountability of university: Transition of public higher education. Entrepreneurial Business and Economics Review, 4(1), 9-21.

Sułkowski, Ł. (2016b). Kultura akademicka: koniec utopii?. Warszawa: Wydawnictwo Naukowe PWN.

Sułkowski, Ł. (2012). Meta-paradigmatic cognitive perspective in management studies. Argumenta Oeconomica, 2(29), 33-51.

Sułkowski, Ł. (2017). The culture of control in the contemporary university. In M. Izak, M. Kostera, \& M. Zawadzki (Eds.), The future of university education (pp. 85-108). Palgrave Macmillan.

Teece, D.J. (1976). The multinational corporation and the resource cost of international technology transfer. Cambridge, MA: Ballinger Publishing.

Teece, D.J. (2007). Explicating dynamic capabilities: The nature and microfoundations of (sustainable) enterprise performance. Strategic Management Journal, 28(13), 1319-1350.

Teece, D.J. (2009). Dynamic capabilities and strategic management. Oxford: Oxford University Press. 
Welsh, L.S., \& Loustarinen, R. K. (1993). Inward and outward connections in internationalization. Journal of International Marketing, 1, 46-58.

Tsoukas, H. (2017). Don't Simplify, Complexify: From Disjunctive to Conjunctive Theorizing in Organization and Management Studies. Journal of Management Studies, 54(2), 132-153.

Weick, K. (1995). Sensemaking in Organizations. Thousand Oaks, CA: Sage.

Wright, M., Lockett, A., Clarysse, B., \& Binks, M. (2006). University spin-out companies and venture capital. Res Policy, 35(4), 481-501.

Young, S., Dimitratos, P., \& Dana, L.P. (2003). International entrepreneurship research: what scope for international business theories. Journal of International Entrepreneurship, 1, 31-42.

Zahra, S.A., Zheng, C., \& Yu, J. (2018). Learning advantages of newness: A reconceptualization and contingent framework. Journal of International Entrepreneurship, 16, 12-37. 


\section{Authors}

The contribution share of authors is equal and amounted to $50 \%$ each of them.

\section{Łukasz Sułkowski}

Full professor at Jagiellonian University in Krakow (Poland) and full professor at the University of Social Sciences in Łódź (Poland). His research interests include management in higher education institutions, the economics of higher education, family firms, the methodology of management. Correspondence to: Prof. Łukasz Sułkowski, PhD, University of Social Sciences in Łódź, Departament of Management, ul. Sienkiewicza 9, 90-113 Łódź, Poland, e-mail:

Isulkowski@san.edu.pl

ORCID (i) http://orcid.org/0000-0002-1248-2743

\section{Zofia Patora-Wysocka}

Vice-rector and professor of the University of Social Sciences in Łódź (Poland). PhD in Management (Politechnika Częstochowska). Her research interests include organisational change management, international entrepreneurship, organisation and management theory, organisational behaviour.

Correspondence to: Dr Zofia Patora-Wysocka, University of Social Sciences in Łódź, Departament of Management, ul. Sienkiewicza 9, 90-113 Łódź, Poland, e-mail: zpatora-wysocka@san.edu.pl ORCID (1) http://orcid.org/0000-0002-0429-0207

\section{Acknowledgements and Financial Disclosure}

The article was financed from scientific funds of the University of Social Sciences in Lodz.

\section{Copyright and License}

This article is published under the terms of the Creative Commons

Attribution - NoDerivs (CC BY-ND 4.0) License

http://creativecommons.org/licenses/by-nd/4.0/

Published by Cracow University of Economics - Krakow, Poland 